\title{
The Value of Academic Libraries: Library Services as a Predictor of Student Retention
}

\section{Adam Murray, Ashley Ireland, and Jana Hackathorn}

This study examined the predictive relationship between library use by individual students and their retention status in university settings. The methodology builds on a small number of previous studies to examine library use at the individual level to determine if use of specific library services is predictive of retention for freshmen and sophomores. Binary logistic regression yielded results that indicate a strong positive predictive relationship between library use of any kind with both freshmen and sophomore retention. These results suggest that academic libraries add value to institutional retention efforts.

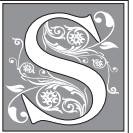

tudent retention is an increasingly critical issue for institutions of higher education, with far-reaching effects on many other areas of life, including the well-being of students and society. Institutions of higher education face greater calls for accountability regarding different performance metrics, among them student retention and completion of degree programs. State legislatures and higher education coordinating agencies increasingly connect state funding with graduation rates. ${ }^{1}$ Institutions of higher education are often pressured to keep costs contained, while serving more students who lack the skills necessary to succeed in college. Frequent limitations to increases in tuition as a means of offsetting lost state appropriations lead to both enrollment and retention as high-stakes endeavors, not just for university administrators but also for students and society. ${ }^{2}$ Seidman provided a clear summary of the wide-ranging impact of student dropout:

Attrition results in a severe loss of resources by society, by students, and by colleges that spend to provide programs and services to help retain and graduate students. When a student leaves college prematurely, any debt incurred must be repaid, despite the failure to graduate, and the college loses future funding in the form of tuition and fees and auxiliary services (bookstore, food service, and so forth) generated over time. The surrounding college community that supports the college, restaurants, movie theaters, and so on, also suffers an adverse economic impact when students leave. In addition, students may be turned off to the educational system in general, never returning to benefit from educational opportunities that may have helped with job

Adam Murray is Dean of Libraries $\mathcal{E}$ Educational Technologies at James Madison University; e-mail: murrayal@jmu.edu. Ashley Ireland is Dean of University Libraries and Jana Hackathorn is Associate Professor of Psychology, both at Murray State University; e-mail: aireland@murraystate.edu, jhackathorn@ murraystate.edu. (C) 2016 Adam Murray, Ashley Ireland, and Jana Hackathorn. 
attainment, enhancement, or advancement. College graduates also earn more money over a lifetime, incur fewer health problems, suffer less penal involvement, and live longer than non-college graduates. ${ }^{3}$

Just as the indicators of quality and success used by postsecondary institutions are evolving, so too are the metrics used to assess the impact and value of units within higher education institutions, including academic libraries. Academic libraries, seeking to demonstrate their relevance in a performance-funding environment, will find little guidance on how to appropriately gather data or communicate impact to university administrators. ${ }^{4}$

Librarians working in academic libraries are eager to engage in initiatives supporting university priorities, even those that do not directly involve the library. "This represents a significant turn from the time-honored practice of measuring success against peer libraries, in favor of judging ourselves by how libraries help their institutions succeed. ${ }^{\prime 5}$ Academic library directors and librarians seeking methods of impact on student retention will find little help in the body of scholarly study. Lynch et al. found that, while provosts expect academic libraries to contribute to areas of institutional priority, such as enrollment and retention initiatives, they had little guidance on how to connect library practice to these areas. ${ }^{6}$ Indeed, the academic library may have played a passive role in such areas, with the result that their contributions are overlooked. ${ }^{7}$

Student engagement in certain educationally purposeful activities, such as first-year experiences, common intellectual experiences, writing-intensive courses, and service learning, has been noted repeatedly as impacting students' satisfaction level with an institution, thus impacting departure decisions. ${ }^{8}$ Yet, a surprisingly high percentage of students are not engaged with their education in meaningful ways. ${ }^{9}$ Kuh indicated higher education institutions could take immediate steps toward improving engagement and retention by intentionally targeting different student populations with interventions bearing historical evidence of effectiveness. ${ }^{10} \mathrm{Kuh}$ and Gonyea noted that educationally purposeful activities that nurture student engagement often require students to spend a considerable amount of time outside a formal classroom environment and that academic libraries provide an ideal informal academic environment for these types of practices. ${ }^{11}$

This study's central question is "how does known library use affect students' persistence?" A number of relevant research questions are derived from this central question. These research questions ask whether use of various library resources or services predict increases in student persistence. Specific library resources or services examined are use of physical library collections, library electronic resources (such as databases), library computer lab usage, use of interlibrary loan/document delivery, participation in library instruction sessions, enrollment in credit-bearing information literacy courses, and use of a library-managed writing center and communication center.

\section{Literature Review}

While the demand for research into the value of academic libraries to institutional priorities is relatively recent, studies of the impact of academic libraries on retention date much further back. Of particular note is Kramer and Kramer's study, which is one of the earliest scholarly studies of the connection between academic libraries and retention. ${ }^{12}$ This early study was conducted using a convenience sample of entering freshmen at California State Polytechnic College, Pomona. Numbers indicating how many books were "checked out" were used as indicators of library use, a metric appropriate for the time period. Kramer and Kramer found that 43 percent of library nonusers dropped out after their first year while only 26 percent of library users dropped out. These findings demonstrated that library users had a higher rate of retention $(73.7 \%)$ than the overall institutional rate of 63 percent. 
More recently, Hubbard and Loos conducted a survey of 321 academic library deans on the extent to which academic libraries participate in enrollment and retention initiatives. ${ }^{13}$ They reported that 40.1 percent of respondents indicated that the library hosts or sponsors events specifically intended to encourage student retention. The coding descriptions of these library-hosted events included (in decreasing order of frequency) campus engagement/student programming, instruction, student support services, study space/facilities, open houses/orientations/tours, liaison programs, student employment, and library services. Most of the respondents "pointed to standard academic library services and facilities as being important to retention efforts" (177). Other comments indicate the desire to develop effective mechanisms for conducting a robust study of the library's impact on retention.

Mezick conducted a study on associations between a culture of assessment within Association of Research Libraries (ARL) and student persistence. ${ }^{14}$ Mezick's study drew on the data gathered in 2007 by Wright and White on library assessment, combined with institutional fall-to-fall retention rates reported to the Integrated Postsecondary Education System (IPEDS). Mezick found no statistically significant correlations between indicators of a culture of assessment in member libraries (such as longevity of library assessment activities or the provision of assessment training for library employees) and retention. This finding drew Mezick to conclude that libraries need to "participate in the identification of specific indicators of performance that will generate the data and documentation needed to assess" value outcomes (35).

Generally, there are two broad methods used in studies of library impact on retention. Crawford's study on Pennsylvania academic libraries and retention provides an example of one method - the use of institutional variables and institutional retention rates to calculate correlations. ${ }^{15}$ Crawford made use of data provided by IPEDS and the Academic Library Survey (ALS) to calculate a "total library service index per FTE." This index variable was composed of the sum of total number of circulations, interlibrary loans, visitor counts, attendance at instruction sessions, and reference transactions, divided by institutional FTE. The resulting variable acted as a surrogate for library use and was analyzed in conjunction with the institutional six-year graduation rate and institutional total library expenditure. While Crawford found a positive and significant correlation between total library service index and retention, it accounted for a small percentage of the variation. Crawford also conducted a multiple regression analysis to determine if total institutional library expenditure or the total library service index was predictive of retention. This model did not show any significant predictive relationship between institutional library expenditures or library use with retention. However, Crawford noted that the total library service index variable did not include the use of online resources, which would account for a significant portion of the total institutional library expenditure variable.

Eng and Stadler's recent study provides another example of institutional-level data being used to determine library impact on retention. ${ }^{16}$ Using the ACRL Metrics database, they retested the correlational relationship between library expenditures and student retention found in a previous study by Mezick. ${ }^{17}$ While they found that some institution types could no longer show a strong relationship between library expenditures and student retention, as had been true in previous research, they did find that a correlation remains between library FTE and student retention.

Other studies, such as Haddow and Joseph's, use a methodology that draws upon data of library use and retention status at the individual level, rather than at the institutional level. ${ }^{18}$ Haddow and Joseph's study made use of library usage data for each student (number of items borrowed, number of logins to a PC physically housed in the library, and number of online logins to library systems such as databases, ILL, and 
the like). Numeric values for these uses were categorized into high use, medium use, low use, and no use fields, and analyzed using the nonparametric statistical (MannWhitney) tests to determine associations between library use and retention. The results showed that a high proportion of withdrawn students had no or low use of library resources, particularly if those withdrawn students made no use of library resources early in the semester. The authors suggested academic librarians should focus efforts on library instruction and entry into the facility early in the first semester in an effort to maximize their impact on retention.

Haddow followed this study with further examinations. The follow-up study compiled demographic and retention data at three points in the first year: at the end of semester 1 , reenrolled in semester 2, retained at the end of semester 2. Library login data (authentication for electronic resources and loans) were also collected at three points in the first year. The authors found that retained students logged into library resources at a much higher rate than withdrawn students, regardless of the time in the semester of withdrawal. ${ }^{19}$

Similar to Haddow's study, Soria, Fransen, and Nackerud focused their study on library use early in an undergraduate program - in this case, the first semester of the first year. ${ }^{20}$ Their study examined library use correlated with first-year, first-semester academic achievement and retention, examining specific library services and controlling for demographic characteristics, precollege academic characteristics, and students' other experiences on campus. Their list of indicators of library use included logins at library computer terminals, logins to licensed library resources, circulation data, and interlibrary loan usage. Specific controls for this study included: gender, race/ethnicity, international status, Pell grant award status, status as a first-generation college student, military veterans, and precollege academic characteristics (ACT composite score and Advanced Placement credits). Results included findings of a significant correlation between library usage and retention from the first semester to the second semester, along with positive correlations with GPA. Specific library services with strong positive correlations to retention included enrollment into an information literacy workshop and the use of online databases.

These findings were further supported in a follow-up study by Soria, Fransen, and Nackerud, in which the researchers used the 10 library use data elements and two statistical analyses (ordinary least square regressions and logistic regression) to predict first-year students' cumulative grade point averages and first-year to second-year retention. ${ }^{21}$ Use, even once, of library databases, print collections, electronic journals, and computer workstations were positively correlated with GPA and retention. For every additional time that students engaged in these behaviors, students demonstrated an associated increase in GPA and retention. This connection between the use of the physical and electronic collections and student success (such as freshman-to-sophomore retention, persistence to graduation, and GPA) was also found by Stemmer and Mahan, who correlated self-reported library use with retention, graduation rates, and GPA. ${ }^{22}$ Stemmer and Mahan found that academic (as opposed to personal) use of library services that are facilities- or space-related had a stronger correlation with indicators of student success in the freshmen and sophomore years. This correlation fades in the junior and senior years, while the correlation between use of the information resources provided by the library and student success continues from the underclassmen years and grows stronger in the upperclassmen years.

The study presented here builds on the methodology used by Haddow and Soria, Fransen, and Nackerud, namely examining library use or nonuse data of individuals and correlating that data with their specific retention status. 


\section{Methodology}

The methodology used for this study was similar to the studies conducted by Soria et al., Haddow, and Haddow and Joseph.

\section{Participants}

For the current study, a total of 3,757 students' records were pulled from the spring 2013 semester at a regional public university in the Midwest. There was a total of 1,567 males and 2,190 females. Ages ranged from 17 to 83 years of age $(M=21.91, S D=6.47, \mathrm{Med}=$ 20.5). The ethnic breakdown of the students was predominantly Caucasian $(n=2,926$; $78 \%)$, but also included other ethnicities: African-American/Black $(n=286)$, Hispanic $(n=64)$, Asian $(n=28)$, Native American $(n=3)$, Pacific Islander $(n=2)$, Multiracial $(n=70)$, and International Students $(n=299)$. Data was missing for 77 students. See table 1 for a breakdown of demographics between freshman and sophomore students. Freshmen are defined by the university as students who have completed and earned credit for no more than 29 hours, and sophomores are defined as having completed and earned credit for at least 30 hours but no more than 60 . This status was captured as part of the data aggregated by the Registrar's Office.

\begin{tabular}{|c|c|c|}
\hline \multicolumn{3}{|c|}{$\begin{array}{l}\text { TABLE } 1 \\
\text { Demographic Breakdown of Freshmen and Sophomore Students in Spring } \\
2013 \text { Semester }\end{array}$} \\
\hline Demographic & Freshmen & Sophomore \\
\hline \multicolumn{3}{|l|}{ Gender } \\
\hline Male & $952(42.0 \%)$ & $615(41.3 \%)$ \\
\hline Female & $1315(58.0 \%)$ & $875(58,7 \%)$ \\
\hline Age & $\mathrm{M}=21.88, \mathrm{SD}=7.84$ & $\mathrm{M}=21.94, \mathrm{SD}=5.10$ \\
\hline \multicolumn{3}{|l|}{ Ethnicity/Race } \\
\hline Caucasian & $1,683(74.2 \%)$ & $1,243(83.4 \%)$ \\
\hline African American/Black & $169(7.5 \%)$ & $117(7.9 \%)$ \\
\hline Hispanic & $42(2.0 \%)$ & $22(1.5 \%)$ \\
\hline Asian & $20(<1 \%)$ & $8(<1 \%)$ \\
\hline Native American & $2(<1 \%)$ & $3(<1 \%)$ \\
\hline Pacific Islander & $1(<1 \%)$ & $1(<1 \%)$ \\
\hline Multiracial & $49(2.2 \%)$ & $21(1.4 \%)$ \\
\hline International Students & $247(10.9 \%)$ & $52(3.5 \%)$ \\
\hline Missing & $54(2.4 \%)$ & $23(1.5 \%)$ \\
\hline
\end{tabular}




\section{Materials and Procedure}

This study relied on the collection of data for individual library users for each of a variety of library services or resources. Because each variable (in other words, individual use of specific library services or resource) had different sources of data, the data of individual use of specific library resources had to be gathered from each related system and collated in a central database. The central database of individual library use was constructed using the dataset of authorized users generated by the institution's enterprise management system, Banner. Authorized users included enrolled students and currently employed faculty and staff, including adjuncts. An institution-issued identification number served as the key for linking individual use data across the different library systems. A description of the source of data for each variable follows.

Use of physical library collections (Checkouts). Physical library resources included books, media, and laptops/equipment available for circulation. These data were obtained from the library's integrated library system (ILS) Voyager. Authorized users who checked out a physical resource from the library were coded 1 ; nonusers were coded 0 . The data were retrieved monthly and aggregated in the central database.

Electronic resources (EZP). Authorized users of library electronic resources are verified through logging into a proxy server, which serves as the source of data for this variable. Because of the implementation of a new discovery system prior to the study, the proxy server was configured to require authentication for all users, regardless of whether they were located on-campus or off-campus. Credentials for logging into the proxy server relied on active directory username, which is identical to institutional email address. E-mail address was cross-walked to the institution-issued identification number in the dataset of authorized users. Authorized users who logged into library electronic resources were coded 1 ; nonusers were coded 0 . The data were retrieved monthly and aggregated in the central database.

Library computer lab usage (Lab). This variable served as a surrogate for presence in the library facility. As with use of library electronic resources, use of library computer labs relied on the active directory username, which was cross-walked in the dataset of authorized users to the institution-issued identification number. Authorized users who logged into library computer labs were coded 1 ; nonusers were coded 0 . The data were retrieved yearly from the lab management system and aggregated in the central database.

Use of the interlibrary loan system (ILLiad). The ILLiad system is self-populated by library users with their institution-issued identification number and verified by interlibrary loan staff. Authorized users who submitted interlibrary loan requests were coded 1 ; nonusers were coded 0 . The data were retrieved each semester from ILLiad and aggregated in the central database.

Participation in library instruction sessions (Inst Sessions). Course and section numbers were gathered each semester for classes in which the instructing faculty member requested a library instruction session. From this, a data request to the institution's registrar's office solicited the institution-issued identification number for students enrolled in those sections of courses. It must be noted that these data do not account for absenteeism; whether individual students were present the day of a library instruction session is not known. Students enrolled in these courses for which library instruction was provided were coded 1; students enrolled in courses without library instruction were coded 0 . The data were collected each semester and aggregated into the central database.

Enrollment in credit-bearing information literacy courses (INF). This variable consisted of students enrolled in credit-bearing information literacy courses taught by the members of the library faculty. INF 101 is a three-credit general studies elective and 
is taught in both sixteen-week and eight-week (accelerated) offerings during fall and spring semesters. The institution-issued identification number for students enrolled in INF 101 were provided to the manager of the central database. Enrolled students were coded 1; all other students not enrolled in the course were coded 0.

Use of a library-managed writing center (Writing Center). This data consisted of data related to student use of a writing center housed and administered by the library. The center provides writing consultations for all students, regardless of academic discipline. Students using the center checked in as they entered the center, providing their institution-issued identification number. Students who made use of the writing center were coded 1 ; students who did not were coded 0 . The data were collected each semester of the academic year and aggregated into the central database.

Use of a library-managed oral communication center (Comm Center). This variable is related to student use of an oral communication center housed in and administered by the library. Students using the center checked in as they entered the center, though their institution-issued identification number was not collected. Using the names of users, the institution-issued identification number was obtained from the university's enterprise resource system, Banner. Student who made use of the oral communication center were coded 1; students who did not make use of the oral communication center were coded 0 . The data were collected each semester of the academic year and aggregated into the central database.

\begin{tabular}{|c|c|c|c|c|c|c|}
\hline \multicolumn{7}{|c|}{$\begin{array}{c}\text { TABLE } 2 \\
\text { Library Use for Freshmen and Sophomores }\end{array}$} \\
\hline & \multicolumn{2}{|c|}{ Freshmen $(n=2,267)$} & \multicolumn{2}{|c|}{ Sophomores $(n=1,490)$} & \multicolumn{2}{|c|}{ Total $(\mathrm{N}=\mathbf{3 , 7 5 7})$} \\
\hline Service & Used & Refrained & Used & Refrained & Used & Refrained \\
\hline Overall & $\begin{array}{l}1,423 \\
(63 \%)\end{array}$ & $844(37 \%)$ & $\begin{array}{l}1,178 \\
(79 \%)\end{array}$ & $\begin{array}{c}312 \\
(21 \%)\end{array}$ & $\begin{array}{c}2,601 \\
(70 \%)\end{array}$ & $\begin{array}{c}1,156 \\
(31 \%)\end{array}$ \\
\hline Check Out & $\begin{array}{c}454 \\
(20 \%)\end{array}$ & $\begin{array}{l}1,813 \\
(80 \%)\end{array}$ & $431(29 \%)$ & $\begin{array}{l}1,059 \\
(71 \%)\end{array}$ & $\begin{array}{c}739 \\
(20 \%)\end{array}$ & $\begin{array}{l}2,872 \\
(80 \%)\end{array}$ \\
\hline EZP & $\begin{array}{c}349 \\
(15 \%)\end{array}$ & $\begin{array}{l}1,918 \\
(85 \%)\end{array}$ & $285(19 \%)$ & $\begin{array}{l}1,205 \\
(81 \%)\end{array}$ & $\begin{array}{c}634 \\
(17 \%)\end{array}$ & $\begin{array}{l}3,123 \\
(83 \%)\end{array}$ \\
\hline Lab & $\begin{array}{c}893 \\
(39 \%)\end{array}$ & $\begin{array}{l}1,374 \\
(61 \%)\end{array}$ & $810(54 \%)$ & $680(46 \%)$ & $\begin{array}{l}1,703 \\
(45 \%)\end{array}$ & $\begin{array}{l}2,054 \\
(55 \%)\end{array}$ \\
\hline Illiad & $22(1 \%)$ & $\begin{array}{l}2,245 \\
(99 \%)\end{array}$ & $34(2 \%)$ & $\begin{array}{l}1,456 \\
(98 \%)\end{array}$ & $56(1 \%)$ & $\begin{array}{l}3,701 \\
(99 \%)\end{array}$ \\
\hline $\begin{array}{l}\text { Inst } \\
\text { Sessions }\end{array}$ & $\begin{array}{c}315 \\
(14 \%)\end{array}$ & $\begin{array}{l}1,952 \\
(86 \%)\end{array}$ & $168(11 \%)$ & $\begin{array}{l}1,322 \\
(89 \%)\end{array}$ & $\begin{array}{c}483 \\
(13 \%)\end{array}$ & $\begin{array}{l}3,274 \\
(87 \%)\end{array}$ \\
\hline INF & $\begin{array}{c}16 \\
(<1 \%)\end{array}$ & $\begin{array}{l}2,251 \\
(99 \%)\end{array}$ & $16(1 \%)$ & $\begin{array}{l}1,474 \\
(99 \%)\end{array}$ & $\begin{array}{c}32(< \\
1 \%)\end{array}$ & $\begin{array}{l}3,725 \\
(99 \%)\end{array}$ \\
\hline Writing Ctr & $\begin{array}{c}44 \\
(<1 \%) \\
\end{array}$ & $\begin{array}{l}2,223 \\
(99 \%) \\
\end{array}$ & $29(2 \%)$ & $\begin{array}{l}1,461 \\
(99 \%)\end{array}$ & $73(2 \%)$ & $\begin{array}{l}3,684 \\
(98 \%)\end{array}$ \\
\hline Comm Ctr & $21(1 \%)$ & $\begin{array}{l}2,246 \\
(99 \%)\end{array}$ & $18(1 \%)$ & $\begin{array}{l}1,472 \\
(99 \%)\end{array}$ & $39(1 \%)$ & $\begin{array}{l}3,718 \\
(99 \%)\end{array}$ \\
\hline
\end{tabular}




\section{Results}

To examine which library services could predict retention at the end of the academic year, two sets of analyses were conducted for both the freshman and the sophomores. Library use, as well as each individual service, in the spring 2013 academic semester were used as the primary predictors of whether students were retained in the fall 2013 semester. Note: The outcome of the analysis represents the odds ratio of retention. See table 2 for the frequency of service use between freshman and sophomores. (Note: Due to a threat of multicollinearity, library use as a whole was entered into a regression analysis separate from each of the individual services). ${ }^{23}$

For the first analysis, library use as a whole was entered as a primary predictor of retention. Overall, library use can predict retention $(\chi 2=575.72, p<.001$, Nagelkerke $R 2=.31)$. Specifically, the results indicate that freshman library use $(\beta=2.26, \mathrm{OR}=$ $9.54, p<.001)$ in the spring semester positively predicted retention in the subsequent fall semester. Simply put, a freshman student at this institution who uses the library is 9.54 times more likely to be retained. Additionally, the same analysis indicated that, for sophomores, library use predicted retention $(\chi 2=84.03, p<.001$, Nagelkerke $R 2=.10)$. Specifically, library use $(\beta=1.44, \mathrm{OR}=4.23, p<.001)$ in the spring semester positively predicted retention in the subsequent fall semester, in that students at this institution who used the library were 4.23 times more likely to be retained.

As a second, more specific analysis, each individual service offered by the library was examined as a predictor of retention. The predictability of using library services was significant for both freshmen $(\chi 2=181.13, p<.001$, Nagelkerke $R 2=.11)$ and for sophomores $(\chi 2=17.92, p=.022$, Nagelkerke $R 2=.02)$. Findings suggest that checkouts and EZP are both positive predictors of retention regardless of class (whether freshman or sophomore). Additionally, the comm center and lab are significant predictors of retention for freshman, whereas EZP was a significant positive predictor for sophomores. Conversely, the writing center was a negative predictor for freshmen, and INF was a negative predictor for sophomores. See table 3 for the numerical details regarding the individual significant predictors of retention, for both freshmen and sophomores.

\begin{tabular}{|c|c|c|c|c|c|c|c|c|}
\hline \multicolumn{9}{|c|}{$\begin{array}{c}\text { TABLE } 3 \\
\text { Retention Predicted from Individual Library Services, between Freshmen } \\
\text { and Sophomores }\end{array}$} \\
\hline & \multicolumn{4}{|c|}{ Freshmen } & \multicolumn{4}{|c|}{ Sophomores } \\
\hline Service & B & SE & Wald & OR & B & SE & Wald & OR \\
\hline Check Out & 0.55 & 0.14 & 15.52 & $1.73 * * *$ & 0.32 & 0.18 & 3.04 & $1.38 *$ \\
\hline EZP & 0.81 & 0.15 & 29.26 & $2.26 * * *$ & 0.53 & 0.23 & 0.51 & $1.69 *$ \\
\hline Lab & 0.81 & 0.11 & 57.71 & $2.25 * * *$ & 0.02 & 0.16 & 0.02 & 1.02 \\
\hline Illiad & 0.02 & 0.50 & 0.00 & 1.02 & 0.72 & 0.74 & 0.93 & 2.04 \\
\hline $\begin{array}{l}\text { Inst } \\
\text { Sessions }\end{array}$ & -0.13 & 0.14 & 0.86 & 0.88 & -0.11 & 0.25 & 0.19 & 0.90 \\
\hline INF & -0.15 & 0.66 & 0.05 & 0.86 & -1.47 & 0.58 & 6.40 & $0.23 *$ \\
\hline Writing Ctr & -0.95 & 0.35 & 7.44 & $0.39 * *$ & -0.68 & 0.48 & 2.01 & 0.51 \\
\hline Comm Ctr & 1.40 & 0.77 & 3.31 & $4.022 *$ & 0.97 & 1.05 & 0.85 & 2.64 \\
\hline
\end{tabular}




\section{Discussion}

Crawford's study used regression analysis to predict retention and graduation based on total institutional library expenditures and a total library service index per FTE variable serving as a surrogate for library use. ${ }^{24}$ The current study included a variable "library use as a whole," which was generated if the student used any of the various library service indicators. This variable, captured at the level of the individual and correlated with individual retention status, is analogous to Crawford's total library service index per FTE, which was correlated with institutional retention rates. Using institutional data, Crawford's regression analysis found no predictive relationship between institutional library expenditures or library use with retention. The current study, using individual-level library use and retention status data, found the opposite relationship. This study found library use - of any kind - was predictive of freshman-to-sophomore and sophomore-to-junior retention, with freshman library users being nine times more likely to be retained than nonusers. Sophomore library users were four times more likely to be retained than nonusers. Using the academic library for any reason was a significant positive predictor of retention for all of the students in the population.

Within this key finding are a number of related findings on the use of specific library services. For freshmen, checking items out, using electronic library resources, using the communication center, and using the library computer labs were all positive predictors of a greater likelihood of retention. This is consistent with the findings reported by Soria et al. ${ }^{25}$ With the exception of use of electronic library resources, each of these positive predictors of retention require students to be physically present in the library. Checking items out and using the communication center take physical presence in the library one step further, as these services require interaction and engagement with library employees. Students using the library computer labs are also often observed working together at a single terminal. That is, although only one student may be logged in (and hence examined in this study), two or more students may actually be working together at a single computer.

Sophomores demonstrated a different pattern of predictive correlations between library use or nonuse and retention. For sophomores, checking items out and using electronic library resources were the biggest predictors. Interestingly, while sophomore use of library computer labs increased over that of freshmen, its predictive significance decreased. Likewise, use of the communication center by sophomores showed less predictive power than it did for freshmen. In the case of the communication center, this pattern could be explained by an increase in student stress brought about by a required freshman-level oral speaking class. The increase in stress related to oral communication could potentially lead to a greater impact in the freshman year of a support center specifically for coaching students through speaking assignments. One other possible explanation for the diminished predictive power of use of the library computer labs is financial considerations. Sophomores tend to receive less scholarship support than do freshmen, which may simultaneously lead sophomore students to increase their use of university-provided equipment such as the library computer labs while also increasing the strain on their finances. Financial aid data were not included in the dataset requested from the registrar in the current study. Further study on the correlations between financial aid and scholarship awards, library use, and retention is needed.

One final explanation may be investment. That is, students who are more invested, involved, and engaged in their learning tend to use information and resources outside the classroom, more than students who are less invested or engaged in their education. An additional caveat is that the students who are more involved tend to experience greater benefits in learning and student development that are ultimately also useful in predicting retention. ${ }^{26}$ 
Nonuse of these services, in and of themselves, may not directly impact students' decisions to withdraw, but they may be a reflection of a lack of engagement and thus may be a predictive indicator of students who are not in contact with university employees or other students who could serve as a support network. This study's methodologyand that of a small but growing research community-makes use of individual data to calculate predictive indicators of retention. The capturing and analysis of individual use data allows not only for a more specific examination of correlations than the use of institutional-level data, it also creates an opportunity for academic libraries to become a more proactive partner in universities' perennial quest to engage and retain students. By determining library services or resources that yield predictive results, academic libraries could work with retention offices, advisors, and other academic and student support units to develop and provide tailored interventions that may positively affect a student's decision to remain enrolled, particularly for students with low or no use of certain library services. An enhanced, highly sophisticated data analysis may include the element of time and make recommendations. For instance, students in a certain course who have not yet used an electronic resource may be flagged for an "academic wellness check." As it is now, retention efforts are being designed around automation and human intervention, based on the available technology. These metrics enhance those efforts.

As with any assessment, the use of the results should inform the application and implementation of new or refined library services. Individual-level data, far beyond simple library use numbers that cannot be tied to demographics, can help guide strategic planning, budget requests, and staffing decisions. In the case of the institution under study in this article, the finding that the use of the communication center had a positive correlation with retention was used - successfully - to secure additional funding for the center's operation, and efforts are being made to do the same for the writing center. Likewise, analysis of this type can also be used to inform renovation plans and designs. Finally, analysis of individual-use data can be used to help structure and refine such initiatives as general education curricula, freshman experiences, orientations, and other high-impact engagement and retention activities.

There are some limitations to note with this study. As with any study involving correlational analysis, the findings should not be interpreted in a causal fashion. For example, the negative regression coefficients found for freshmen who use the writing center should not be interpreted that use of the writing center leads one to withdrawal from an institution of higher education. Instead, it could be interpreted that students' need to use the writing center is more related to their at-risk levels. Specifically, the majority of students who use the writing center lack college-level writing skills. For example, some of the students are international students, for whom English is their second language, while others are students who scored low on standardized tests and may be required to use the writing center as part of their remedial language courses. Instead of inferring that the writing center leads to lower retention, this information can be used to find and potentially assist those at-risk students.

Another limitation relates to the source of data for the checkout variable. To protect library user privacy, the specific types of items checked out by students could not be disaggregated. As a result, checkouts include not only traditional book checkouts but also laptops, iPads, and other technology or equipment. It would be more accurate for the purpose of analysis if circulations of technology and other equipment could be assessed alongside lab logins, but that was simply not possible with the ILS and systems available. More analysis is necessary to determine how engagement with physical technology via the university library may predict retention.

Overall, this study helps demonstrate the role that academic libraries and the services and resources provided by academic library employees can play in retaining 
students. In an age when many view the library as having a diminished role because "everything is online," these findings help library administrators and university leaders understand the value academic libraries can provide to institutional retention efforts. Given this study's findings that checking out items from the library or using electronic library resources have a significant positive predictive relationship with retention, the perception of library expenditures as a drain on institutional finances with no discernable return-on-investment is weakened. This study empowers library administrators to create the infrastructure necessary to determine the relationship between known library use at the individual level and student retention at their own institution.

\section{Notes}

1. Thomas Bailey, Research on Institution Level Practice for Postsecondary Student Success (Washington, D.C.: National Postsecondary Education Cooperative [NPEC], 2006), 5.

2. Gerald McLaughlin, Paul Brozovsky, and Josetta McLaughlin, "Changing Perspectives on Student Retention: A Role for Institutional Research," Research in Higher Education 39, no. 1 (1998): 1-17; Mantz Yorke, "Retention, Persistence and Success in On-campus Higher Education, and Their Enhancement in Open and Distance Learning," Open Learning 19, no. 1 (2004): 19-32.

3. Alan Seidman, "Minority Student Retention: Resources for Practitioners," New Directions for Institutional Research 125 (2005): 7-24.

4. Joseph Matthews, "Assessing Library Contributions to University Outcomes: The Need for Individual Student Level Data," Library Management 33, no. 6 (2012): 389-402; Janice SimmonsWelburn, Georgie Donovan, and Laura Bender, "Transforming the Library: The Case for Libraries to End Incremental Measures and Solve Problems for Their Campuses Now," Library Administration \& Management 22, no. 3 (2008): 130-34.

5. Simmons-Welburn et al., "Transforming the Library," 132.

6. Beverly Lynch, Catherine Murray-Rust, Susan Parker, Deborah Turner, Diane Parr Walker, Frances Wilkinson, and Julia Zimmerman, "Attitudes of Presidents and Provosts on the University Library," College \& Research Libraries 68, no. 3 (2007): 213-27.

7. Megan Oakleaf, Value of Academic Libraries: A Comprehensive Research Review and Report (Chicago: American Library Association, 2010): 28.

8. Shouping Hu and George Kuh, "Being (Dis)engaged in Educationally Purposeful Activities: The Influences of Student and Institutional Characteristics," Research in Higher Education 43, no. 5 (2002): 555-75; Thomas Nelson Laird, Rick Shoup, George Kuh, and Michael Schwarz, "The Effects of Discipline on Deep Approaches to Student Learning and College Outcomes," Research in Higher Education 49, no. 6 (2008): 469-94.

9. Richard Arum and Josipa Roksa, Academically Adrift (Chicago: University of Chicago Press, 2011); Derek Bok, Our Underachieving Colleges (Trenton, N.J.: Princeton University Press, 2006).

10. George Kuh, High-Impact Educational Practices: What They Are, Who Has Access to Them, and Why They Matter (Washington, D.C.: Association of American Colleges and Universities, 2008).

11. George Kuh and Robert Gonyea, "The Role of the Academic Library in Promoting Student Engagement in Learning," College E Research Libraries 4, no. 4 (2003): 256-82.

12. Lloyd Kramer and Martha Kramer, "The College Library and the Drop-out," College \& Research Libraries 29, no. 4 (1968): 310-12.

13. Melissa Hubbard and Amber Loos, "Academic Library Participation in Recruitment and Retention Initiatives," Reference Services Review 41, no. 2 (2013): 157-81.

14. Elizabeth Mezick, "Relationship of Library Assessment to Student Retention," Journal of Academic Librarianship 41, no. 1 (2014): 31-36.

15. Gregory Crawford, "Pennsylvania Academic Libraries and Student Retention and Graduation: A Preliminary Investigation with Confusing Results," Pennsylvania Libraries: Research $\mathcal{E}$ Practice 2, no. 2 (2014): 129-41.

16. Sidney Eng and Derek Stadler, "Linking Library to Student Retention: A Statistical Analysis," Evidence Based Library and Information Practice 10, no. 3 (2015): 50-63.

17. Elizabeth Mezick, "Return on Investment: Libraries and Student Retention," Journal of Academic Librarianship 33, no. 5 (2007): 561-66.

18. Gaby Haddow and Jayanthi Joseph, "Loans, Logins, and Lasting the Course: Academic Library Use and Student Retention," Australian Academic \& Research Libraries 41, no. 4 (2010): 233-44.

19. Gaby Haddow, "Academic Library Use and Student Retention: A Quantitative Analysis," 
Library \& Information Science Research 35, no. 2 (2013): 127-36.

20. Krista Soria, Jan Fransen, and Shane Nackerud, "Library Use and Undergraduate Student Outcomes: New Evidence for Students' Retention and Academic Success," portal: Libraries and the Academy 13, no. 2 (2013): 33-45.

21. Krista Soria, Jan Fransen, and Shane Nackerud, "Stacks, Serials, Search Engines, and Students' Success: First-year Undergraduate Students' Library Use, Academic Achievement, and Retention," Journal of Academic Librarianship 40, no. 1 (2014): 84-91.

22. John Stemmer and David Mahan, "Investigating the Relationship of Library Usage to Student Outcomes," College \& Research Libraries 77, no. 3 (2016) 359-375.

23. Barry Cohen, Explaining Psychological Statistics, 3rd Edition (Hoboken, N.J.: John Wiley \& Sons, Inc., 2008).

24. Crawford, "Pennsylvania Academic Libraries and Student Retention and Graduation."

25. Soria et al., "Stacks, Serials, Search Engines, and Students' Success."

26. Alexander Astin, "What Matters in College?" Liberal Education 79, no. 4 (1993): 4-16. 